\title{
Current Opinion of Obstetricians on the Prescription of Emergency Contraception: A German-American Comparison
}

\section{Aktuelles frauenärztliches Meinungsbild zur Verordnung der sogenannten Pille danach: ein deutsch-amerikanischer Vergleich}

Authors

Affiliations
M. David ${ }^{1}$, L. Berends ${ }^{1}$, J. Bartley ${ }^{2}$

${ }^{1}$ Klinik für Gynäkologie, Charité Campus Virchow-Klinikum, Berlin

${ }^{2}$ Klinik für Gynäkologie und Institut für Sexualmedizin, Charité Campus B. Franklin und Charité Mitte, Berlin

\section{Key words}

- emergency contraception

- physician questionnaire

- levonorgestrel

- ulipristal

Schlüsselwörter

- Pille danach

- Ärztebefragung

- Levonorgestrel

- Ulipristal

\section{received 23.7.2012 \\ revised 29.10.2012 \\ accepted $\quad 29.10 .2012$}

Bibliography

DOI http://dx.doi.org/

10.1055/s-0032-1327992

Geburtsh Frauenheilk 2012; 72 :

1004-1008 @ Georg Thieme

Verlag KG Stuttgart . New York . ISSN 0016-5751

\section{Correspondence}

Prof. Matthias David

Charité Campus

Virchow-Klinikum

Klinik für Gynäkologie

Augustenburger Platz 1

13353 Berlin

matthias.david@charite.de

\section{Abstract \\ V}

Background: There are no current studies on the opinions of obstetricians and gynaecologists in Germany about emergency contraception (or post-coital contraception, morning-after pill). The opinions of a large group of physicians were collected using of a questionnaire and compared with the results of an American survey $(n=1154)$. Methods: A two-part questionnaire was used part 1: sociodemographic data, part 2: 4 scenarios to illustrate the possible advantages and disadvantages of free access to emergency contraception as well as 4 indications and situations for which emergency contraception can be prescribed.

Results: The response rate was $91.7 \%(165 / 180$ questionnaires). $63.9 \%$ (103/161) of the German responding physicians were of the opinion that women with access to emergency contraception experienced unwanted pregnancies less frequently than those without access. Merely 26.2\% of the responding physicians supported the prescription-free availability of emergency contraception in apothecaries. The German-American comparison ultimately revealed only a few major differences, e.g., in answers to the question whether or not access to emergency contraception could reduce the number of unwanted pregnancies ( 89 vs. $64 \%$ ).

Conclusions: The high rejection rate of free access to emergency contraception of almost $70 \%$ in our surveyed group supports the current position published by the German Society for Gynaecology and Obstetrics (Deutsche Gesellschaft für Gynäkologie und Geburtshilfe) and the German Professional Union of Gynaecologists (deutscher Berufsverband der Frauenärzte). Since other medical organisations, e.g., WHO, supported the prescription-free access to levonorgestrel formulations as emergency contraception a few years ago, it would be interesting to ask a larger sample of

\section{Zusammenfassung}

$\nabla$

Fragestellung: Es liegen keine aktuellen Studien zum Meinungsbild zur „Pille danach“ von Frauenärztinnen und Frauenärzten in Deutschland vor. Mit einer Befragung sollten Ansichten eines größeren Ärztekollektivs gewonnen und mit den Ergebnissen einer Erhebung in den USA ( $\mathrm{n}=1154)$ verglichen werden.

Methodik: Verwendung fand ein 2-teiliger Fragebogen - Teil 1: soziodemografische Angaben, Teil 2: 4 Szenarien, die mögliche Vor- und Nachteile eines freien Zugangs zur „Pille danach“ darstellen sowie 4 Indikationen und Umstände, unter denen eine Notfallkontrazeption verordnet werden kann.

Ergebnisse: Die Rücklaufquote betrug 91,7\% (165/180 Fragebögen). 63,9\% (103/161) der deutschen Befragten waren der Auffassung, dass Frauen mit Zugang zur „Pille danach“ im Vergleich zu Frauen ohne Zugang dazu weniger häufig ungewollt schwanger werden. Nur 26,2\% der befragten Ärzte befürworteten eine rezeptfreie Abgabe der „Pille danach“ in Apotheken. Der deutsch-amerikanische Vergleich zeigt letztlich nur wenige deutliche Differenzen, z.B. bei der Aussage, ob die „Pille danach“ die Anzahl ungewollter Schwangerschaften senken könne (89 vs. $64 \%$ ).

Schlussfolgerungen: Die hohe Ablehnungsquote einer freien Abgabe der „Pille danach“ von fast $70 \%$ in unserem Befragungskollektiv unterstützt das aktuelle Statement der Deutschen Gesellschaft für Gynäkologie und Geburtshilfe und des deutschen Berufsverbands der Frauenärzte. Da andere medizinische Organisationen z.B. die WHO einen rezeptfreien Zugang zu Levonorgestrel-Präparaten als „Pille danach“ vor einigen Jahren befürwortet haben, wäre die Erhebung einer größeren Stichprobe deutscher Gynäkologinnen und Gynäkologen zur Notfallkontrazeption interessant. 
German gynaecologists and obstetricians about their opinions on emergency contraception.

\section{Introduction}

Emergency (post-coital) contraception with the so-called morning-after pill is in widespread use and has been clinically tested. The so-called morning-after pill is prescribed about 400000 times per year in Germany [1]. Currently, two preparations are in use: the gestagen formulation levonorgestrel (recommended up to 72 hours after unprotected intercourse) and the progesterone receptor modulator ulipristal acetate (recommended up to 5 days after unprotected intercourse). The following side effects have been reported in similar frequencies (ca. $5 \%$ ) for both preparations: headache, breast tension, tiredness, dizziness, lower abdominal pain, and nausea (here a somewhat higher incidence for ulipristal) [2]. For appropriate indications WHO has recommended the administration of emergency contraception without any restrictions [3]. Emergency contraceptives are currently available in more than 140 countries worldwide, 44 of which provide (levonorgestrel) preparations prescription-free over the counter [4]. The German Society for Gynaecology and Obstetrics [Deutsche Gesellschaft für Gynäkologie und Geburtshilfe (DGGG)] and the Professional Union of Gynaecologists (Berufsverband der Frauenärzte) unambiguously support the retention of the prescription requirement stressing the need for comprehensive medical counselling $[5,6]$. Opponents of the prescription-free access to the morning-after pill also fear more risky sexual behaviour and a more carefree attitude towards contraception [7,8,17-19]. On the other hand, supporters of the prescription-free sale of the morning-after pill see an advantage in the unbureaucratic and quicker help for the affected women.

There are no current studies on the opinions of gynaecologists and obstetricians in Germany about the morning-after pill. Thus the aim of this study is to gather the opinions of a larger collective of physicians and to compare them with those of colleagues in the USA. In addition, gynaecologists were asked whether or not the morning-after pill should be available without prescription in Germany.

\section{Methods}

\section{$\nabla$}

A structured questionnaire was used for the survey, based on that used already in 2008/2009 in the USA by Lawrence et al. to collect the opinions of 1760 gynaecologists on the use of the morningafter pill [9]. In addition, the question was posed whether on not the morning-after pill should be available in apothecaries in Germany without prior medical counselling and without prescription requirements. The short questionnaire encompassed 13 items and was split into 2 parts, one sociodemographic (10 questions) and a topic-specific part (3 questions). The questions about social criteria were adapted to the situation in Germany. These questions concerned, among others, gender, age, educational level, professional specialisation, religion, possible immigrant background and regional origins. The topic-specific part contains on the one hand 4 scenarios that present the possible advantages and disadvantages of free access to the morning-after pill. On the other hand, 4 indications and situations are described under which an emergency contraception can be prescribed [9].
Neither the original American questionnaire nor the modified version used in Berlin contained a subdivision according to levonorgestrel and ulipristal acetate preparations but rather referred to the morning-after pill in general; ulipristal acetate was approved in Europe in 2009 and received approval from the FDA for use in USA in August 2010 whereas levonorgestrel preparations have been prescribed for post-coital contraception since the 1990 s.

During a 3-day training conference that was held in Berlin from 18th to 20th November 2011, it was possible within a short period to interview almost 200 gynaecologists. Excluded from the questioning were those participants who were not gynaecologists or who did not practice medicine in Germany. For evaluation of the data the statistics software package SPSS 17.0 (SPSS Inc., Chicago, IL, USA) was used and the number, frequency and mean values were calculated. Differences in frequencies were checked with the exact Fisher test. The significance level was set at $\alpha=1 \%$.

\section{Results}

$\nabla$

A total of 220 participants attended the 3-day training conference, during the first 2 days questionnaires were handed out to 180 participants and 165 completed forms were returned (response quota $91.7 \%$ ). Four questionnaires were not in accord with the above-mentioned inclusion criteria and were not evaluated.

Table 1 Sociodemographic data of the participating collective.

\begin{tabular}{|c|c|c|}
\hline Participating collective & Absolute & $\ln \%$ \\
\hline Male & 28 & 17.4 \\
\hline Female & 133 & 82.6 \\
\hline \multicolumn{3}{|l|}{ Age (in years) } \\
\hline $21-30$ & 27 & 16.8 \\
\hline $31-40$ & 73 & 45.3 \\
\hline $41-50$ & 26 & 16.2 \\
\hline $51-60$ & 16 & 9.9 \\
\hline $61-71$ & 9 & 5.6 \\
\hline \multicolumn{3}{|l|}{ Immigrant background } \\
\hline Yes & 21 & 13.0 \\
\hline No & 136 & 84.5 \\
\hline Not stated & 4 & 2.5 \\
\hline \multicolumn{3}{|l|}{ Region } \\
\hline New federal states & 62 & 38.5 \\
\hline Old federal states & 85 & 52.8 \\
\hline Religion & 112 & 69.6 \\
\hline Christian & 104 & 64.6 \\
\hline - evangelical & 47 & 29.2 \\
\hline catholic & 37 & 23.0 \\
\hline other & 7 & 4.3 \\
\hline Islam & 7 & 4.4 \\
\hline Other & 1 & 0.6 \\
\hline None & 46 & 28.6 \\
\hline Consultant & 57 & 35.4 \\
\hline \multicolumn{3}{|l|}{ Workplace } \\
\hline Hospital & 125 & 78.1 \\
\hline General practice & 35 & 21.9 \\
\hline - non-resident & 4 & 2.5 \\
\hline
\end{tabular}


Table 2 Opinions of the participating collective on the 4 scenarios (A-D)* classified according to subgroups - concurring opinions (values in \% and [n]).

\begin{tabular}{|c|c|c|c|c|c|c|c|c|c|}
\hline & \multirow{3}{*}{$\begin{array}{l}\text { Entire } \\
\text { collective }\end{array}$} & \multicolumn{8}{|l|}{ Scenarios } \\
\hline & & \multicolumn{2}{|l|}{ A } & \multicolumn{2}{|l|}{ B } & \multicolumn{2}{|l|}{ C } & \multicolumn{2}{|l|}{ D } \\
\hline & & $\%(n)$ & p value & $\%(n)$ & $\mathrm{p}$ value & $\%(n)$ & $\mathrm{p}$ value & $\%(n)$ & p value \\
\hline Entire collective & $100(161)$ & $64.0(103)$ & & $32.3(52)$ & & $14.9(24)$ & & $12.4(20)$ & \\
\hline \multicolumn{10}{|l|}{ Gender } \\
\hline Male & $17.4(28)$ & $60.7(17)$ & & $46.4(13)$ & & $28.6(8)$ & & $25.0(7)$ & \\
\hline Female & $82.6(133)$ & $64.7(86)$ & 0.83 & $29.3(39)$ & 0.18 & $12.0(16)$ & 0.04 & $9.8(13)$ & 0.05 \\
\hline \multicolumn{10}{|l|}{ Age } \\
\hline$\leq 30$ & $16.8(27)$ & $55.6(15)$ & 0.51 & $40.7(11)$ & 0.36 & $14.8(4)$ & 1.0 & $11.1(3)$ & 1.0 \\
\hline $31-40$ & $45.3(73)$ & $60.3(44)$ & 0.74 & $26.0(19)$ & 0.16 & $20.6(15)$ & 0.18 & $15.1(11)$ & 0.46 \\
\hline $41-50$ & $16.1(26)$ & $61.5(16)$ & 1.0 & $26.9(7)$ & 0.65 & $7.67(2)$ & 0.37 & $7.7(2)$ & 0.74 \\
\hline $51-60$ & $9.9(16)$ & $75.00(12)$ & 0.41 & $37.5(6)$ & 0.58 & $12.5(2)$ & 1.0 & $12.5(2)$ & 1.0 \\
\hline$\geq 61$ & $5.6(9)$ & $77.8(7)$ & 0.03 & $55.6(5)$ & 0.14 & $11.1(1)$ & 1.0 & $11.1(1)$ & 1.0 \\
\hline Not stated & $6.2(10)$ & $90.0(9)$ & & $40.0(4)$ & & $-(0)$ & & $10.0(1)$ & \\
\hline \multicolumn{10}{|l|}{ Region } \\
\hline New federal states & $38.5(62)$ & $61.3(38)$ & & $30.7(19)$ & & $12.9(8)$ & & $6.45(4)$ & \\
\hline Old federal states & $52.8(85)$ & $67.1(57)$ & 0.49 & $32.9(28)$ & 0.86 & $14.1(12)$ & 1.0 & $10.6(9)$ & 0.56 \\
\hline Not stated & $8.7(14)$ & $57.1(8)$ & & $35.7(5)$ & & $28.6(4)$ & & $50.0(7)$ & \\
\hline \multicolumn{10}{|c|}{ Importance of Religion } \\
\hline $\begin{array}{l}\text { Very important/ } \\
\text { important }\end{array}$ & $33.5(54)$ & $61.1(33)$ & & $35.2(19)$ & & $20.4(11)$ & & $18.5(10)$ & \\
\hline $\begin{array}{l}\text { Less important/ } \\
\text { not important }\end{array}$ & $64.6(104)$ & $64.4(67)$ & 0.73 & $28.8(30)$ & 0.47 & $12.5(13)$ & 0.24 & $6.7(7)$ & 0.03 \\
\hline Not stated & $1.9(3)$ & $33.33(1)$ & & $33.3(1)$ & & $-(0)$ & & $33.3(1)$ & \\
\hline
\end{tabular}

- Table 1 shows the essential sociodemographic data for characterisation of the questioned Berlin group.

A majority, 63.9\% (103/161), of the responders expressed the opinion that women with access to the morning-after pill experienced less unwanted pregnancies than those without access. $32.3 \%(52 / 161)$ of the responding gynaecologists considered the chances to be low that these women would use other methods of contraception, $14.9 \%$ (24/161), believed that these women on average had more sexual partners and $12.4 \%$ (20/161) or the repliers supported the statement that these women or young girls were sexually active earlier in life. In 0 Table 2 the answering behaviour to the 4 scenarios is subdivided according to age, gender, religion etc.

The distribution of the answers of the whole collective to the question about prescription behaviour ("when should emergency contraception be offered to women?") is shown in $\square$ Table 3. A subdivision according to gender, age group, religion etc. did reveal any significant differences.
Only $26.2 \%$ of the responding physicians supported the prescription-free availability of the morning-after pill in apothecaries, merely $4 \%$ were undecided. There were no additional free comments from the responding physicians with regard to the necessity to differentiate between the two hormonal methods. - Table 4 shows the agreement and disagreement with the question subdivided according to age, gender, religion etc.

\section{Discussion}

For the Federal Republic of Germany, there are no current systematic studies about the morning-after pill nor have there been any large-scale studies assessing the opinions of physicians on the topic of emergency contraception. Naturally, the results of the "Berlin questionnaire" presented here can only provide a first impression on the opinions of German gynaecologists in general about this topic. Therefore a larger survey, e.g., under joint organ-

Table 3 Distribution of answers of the participating collective with regard to the morning-after pill $(n=161)$.

The morning-after pill should...

\begin{tabular}{ll} 
Agreement & \\
$\mathbf{n}$ & $\%$ \\
70 & 43.5 \\
70 & 43.5 \\
\hline 5 & 3.1 \\
\hline 2 & 1.2 \\
11 & 6.8 \\
\hline 3 & 1.9 \\
\hline
\end{tabular}


Table 4 Subdivision of the distribution of answers of the participating collective to the question of whether the morning-after pill should be available in apothecaries without prescription (according to subgroups, values in \% and [n]).

\begin{tabular}{|c|c|c|c|c|c|c|c|}
\hline & total & do not & agree & & undecided & & no data \\
\hline & $n$ & $\%(n)$ & $\%(n)$ & $\mathrm{p}$ value & $\%(n)$ & $\mathrm{p}$ value & $\%(n)$ \\
\hline Total & 161 & $68.9(111)$ & $26.1(42)$ & & $4.4(7)$ & & $0.6(1)$ \\
\hline \multicolumn{8}{|l|}{ Gender } \\
\hline Female & 133 & $71.4(95)$ & $25.6(34)$ & & $3.0(4)$ & & $-(0)$ \\
\hline Male & 28 & $57.1(16)$ & $28.6(8)$ & 0.47 & $10.7(3)$ & 0.09 & $3.6(1)$ \\
\hline \multicolumn{8}{|l|}{ Age } \\
\hline$\leq 30$ & 27 & $81.5(22)$ & $11.1(3)$ & 0.08 & $7.4(2)$ & 0.61 & $-(0)$ \\
\hline $31-40$ & 73 & $71.2(52)$ & $23.3(17)$ & 0.57 & $4.1(3)$ & 1.0 & $1.4(1)$ \\
\hline $41-50$ & 26 & $34.6(9)$ & $57.7(15)$ & 0.00 & $7.7(2)$ & 0.35 & $-(0)$ \\
\hline $51-60$ & 16 & $81.2(13)$ & $18.8(3)$ & 0.56 & $-(0)$ & & $-(0)$ \\
\hline$\geq 61$ & 9 & $88.9(8)$ & $11.1(1)$ & 0.44 & $-(0)$ & & $-(0)$ \\
\hline \multicolumn{8}{|l|}{ Region } \\
\hline New federal states & 62 & $80.6(50)$ & $17.7(11)$ & & $1.6(1)$ & & $-(0)$ \\
\hline Old federal states & 85 & $63.5(54)$ & $30.6(26)$ & 0.06 & $5.9(5)$ & 0.40 & $-(0)$ \\
\hline Religion & 112 & $66.1(74)$ & $26.8(30)$ & & $6.2(7)$ & & $0.9(1)$ \\
\hline Christian & 103 & $67.0(69)$ & $27.2(28)$ & & $5.8(6)$ & & $-(0)$ \\
\hline Islam & 7 & $57.1(4)$ & $28.6(2)$ & 1.0 & $-(0)$ & 1.0 & $14.3(1)$ \\
\hline Other & 1 & $-(0)$ & $-(0)$ & & $100.0(1)$ & & $-(0)$ \\
\hline None & 46 & $78.3(36)$ & $21.7(10)$ & 0.43 & $-(0)$ & 0.11 & $-(0)$ \\
\hline \multicolumn{8}{|l|}{ Importance of Religion } \\
\hline Very important/important & 54 & $75.9(41)$ & $20.3(11)$ & & $1.8(1)$ & & $1.8(1)$ \\
\hline Less important/not important & 104 & $66.4(69)$ & $27.9(29)$ & 0,33 & $5.8(6)$ & 0.42 & $-(0)$ \\
\hline Not stated & 3 & $33.3(1)$ & $66.7(2)$ & & $-(0)$ & & $-(0)$ \\
\hline
\end{tabular}

isation of the German Professional Union of Gynaecologists (Berufsverband der Frauenärzte) and the German Society for Gynaecology and Obstetrics (Deutsche Gesellschaft für Gynäkologie und Geburtshilfe) should be undertaken.

In the following paragraphs we want to compare our results with those in the publication by Lawrence et al. (2010) from which we borrowed the original questionnaire [9]. In the USA 1760 gynaecologists were sent questionnaires, the response rate ultimately amounted to $66 \%(n=1154)$ (the responders received a participation motivation of in total 50 dollars). In Berlin, where the survey collective was markedly smaller but the participants did, however, fill out the form on site, which led to a better response rate. Whereas the collective in the American study with $47 \%$ women and $53 \%$ men can be considered to be relatively well balanced, the German study encompassed $82.6 \%$ female and $17.4 \%$ male physicians among whom the female gynaecologists were markedly over-represented since, at present in Germany, the proportion of active female physicians in the field of gynaecology and obstetrics amounts to about 58\% [10]. In the study of Lawrence et al. (2010), moreover, the immigrant background or, respectively, different ethnic origins among the responders (31 vs. 13\%) as well as religious beliefs or preferences ( 89 vs. 70\%) played a greater role than in the medical collective surveyed in Berlin [9]. At first we will recapitulate the answers of the American gynaecologists as to what extent the morning-after pill can influence sexual behaviour in its broader sense: a clear majority held the opinion that the morning-after pill prevented unwanted pregnancies (89\%; questioned German gynaecologists = "G.": 64\%), about one-quarter (27\%; G.: $32 \%$ ) considered that women with access to the morning-after pill used other contraceptive measures to a lesser extent, $15 \%$ thought that they changed their sexual partners more often (G.: $15 \%$ ) and $12 \%$ that they became sexually active at an earlier age (G.: $12 \%$ ).
About one half of the surveyed American gynaecologists would offer the morning-after pill to every woman at risk for an unwanted pregnancy (51\%; G.: 44\%), whereas only very few would limit its use to the victims of sexual assaults (6\%; G.: $3,1 \%$ ) or would not offer it to anyone (6\%; G: $1.2 \%$ ). Not only gender but also religious aspects and regional origins had an impact on opinion making and prescription behaviour among the American collective: thus, male gynaecologists, strongly religious gynaecologists and physicians with an altogether critical attitude towards the morning-after pill would, with a high probability, not prescribe emergency contraception or would prescribe it only for the victims of sexual assaults (odds ratio 2.1-12) [9].

The German-American comparison ultimately discloses only rather moderate differences, e.g., as to whether the morningafter pill can reduce the number of unwanted pregnancies (89 vs. $64 \%$ ). In this context, the questioned German physicians were markedly more sceptical with regard to the statement as seen from a social viewpoint but not with regard to the efficacy of the morning-after pill in concrete cases. Epidemiological surveys in those countries with prescription-free access to the morningafter pill have not yet been able to detect the expected reduction in the number of induced abortions $[11,12]$. Not only the gynaecologists of the American survey but also the participating German gynaecologists probably overestimate the effect of a prescription-free access to the morning-after pill on the number of unwanted pregnancies.

The question as to whether, e.g., levonorgestrel preparations or other preparations should be accessible without prescriptions in apothecaries did not have a correlate in the American study since levonorgesterel preparations are already available without prescription in the USA; under current discussion is the "informed" over-the-counter provision of the morning-after pill to young females under the age of 18 years [13]. In principle, women have the possibility to acquire the morning-after pill without the ne- 
cessity to visit a physician. The influence of the physician on consumption of the pill is thus rather limited. In Germany it is well known that the morning-after pill (at present 2 different preparations) is only available on prescription, the influence of the physician is thus markedly greater. The somewhat liberal behaviour, as expressed in some answers, of the participating German physicians to the morning-after pill could, therefore, be due to the fact that they are fully aware that they are making a decision, assessing the risks, and bearing the responsibility. The American physicians, in contrast, have a definitive opinion but, ultimately, can no longer influence the woman's decision-making process. Currently about two-thirds of the oral emergency contraceptive prescriptions in Germany involve the levonorgestrel preparation PiDaNa and about one-third the ulipristal acetate preparation EllaOne [14]. We have no indications that the participating physicians would favour one or the other preparation or would differentiate between the two should they be made freely available. The decision for or against revoking the prescription requirement should always be a benefit-risk assessment and is ultimately a legislative decision which, however, is most often made after appropriate scientific consultations. On the whole, the rejection quota to free access to the morning-after pill of $69 \%$ of our surveyed collective, however, confirms the current statements of the German Society for Gynaecology and Obstetrics [Deutsche Gesellschaft für Gynäkologie und Geburtshilfe (DGGG)] and the Professional Union of Gynaecologists (Berufsverband der Frauenärzte) $[5,6]$. Other professional medical societies or international organisations such as WHO have supported a prescription-free access to levonorgestrel preparations as morning-after pill for some years. In the USA the FDA recommended in December 2011 that levonorgestrel as morning-after pill should be available to all age groups since it does not exhibit any serious side effects or have any contraindications. However, the US Ministry of Health did not follow the FDA recommendation (see references $[15,16])$.

\section{Conclusion for Practitioners}

\section{$\nabla$}

As already emphasised in the introduction a larger representative survey of the opinions of German gynaecologists on emergency contraception is still lacking. Finally, the current demand and prescription behaviour for the morning-after pill both in general practice and in hospitals (emergency units) should be evaluated scientifically.

\section{Conflict of Interest}

$\nabla$

The authors declare that they have no conflicts of interest.

\section{References}

1 Medimed Spotlight. 4/2010. http://www.medimed.info/spot/Health_ Spotlight_0410.pdf; last access: 2010-11-18

2 Rabe T, Goeckenjan M, Ahrendt HJ et al. Postkoitale Kontrazeption. Gemeinsame Stellungnahme der Deutschen Gesellschaft für Gynäkologische Endokrinologie und Fortpflanzungsmedizin (DGGEF) e.V. und des Berufsverbands der Frauenärzte (BVF) e.V. In: Rabe T, Hrsg. Seminarbuch Gynäkologische Endokrinologie. Heidelberg: Baier Digitaldruck $\mathrm{GmbH} ; 2012$

3 Emergency contraception. Fact sheet No 244 der WHO, revised Oct. 2005. www.who.int/mediacentre/factsheets/fs244/en/index.html; last access: 2012-05-26

4 Cameron ST, Glasier A, Johnstone A et al. Ongoing contraception after use of emergency contraception from a specialist contraceptive service. Contraception 2011; 84: 368-371

5 Deutsche Gesellschaft für Gynäkologie und Geburtshilfe. Notfallkontrazeption gehört in ärztliche Hand. Pressemitteilung vom 29.3.2012. http://idw-online.de/pages/de/news470293; last access: 2012-09-30

6 Albring A. Notfallkontrazeption - Deutschland ist wegweisend. Frauenarzt 2012; 53: 12

7 Rothschild TJ. Switching emergency contraception to over the counter status (letter). NEJM 2003; 348: 82

8 Williams C. New Zealand doctors resist emergency contraception. BMJ 1996; 213: 463

9 Lawrence RE, Rasinski KA, Yoon JD et al. Obstetrician-gynecologist physicians' beliefs about emergency contraception: a national survey. Contraception 2010; 82: 324-330

10 Bundesärztekammer. Ergebnisse der Ärztestatistik zum 31.12.2010. http://www.bundesaerztekammer.de/page.asp?his=0.3.9237; last access: 2012-04-06

11 Glasier A, Fiarurst K, Wyke S et al. Advanced provision of emergency contraception has not reduced abortion rates in Lothian. Contraception 2004; 69: 361-366

12 Raymond EG, Trussell J, Polis CB. Population effect of increased access to emergency contraceptive pills, a systematic review. Obstet Gynecol 2007; 109: 181-188

13 Raine T, Ricciotti N, Sokoloff A et al. An over-the-counter simulation study of a single-tablet emergency contraception in young females. Obstet Gynecol 2012; 119: 772-779

14 IMS Deutschland. Marktanteile der zwei in Deutschland verfügbaren Notfallkontrazeptiva im Bundesdurchschnitt für Juni 2012. Frankfurt/ M.: 2012, www.bionity.com/de/firmen/15736/ims-health-gmbh-coohg.html; last access: 16.11.2012

15 Steinbrook $R$. Science, politics and over-the-counter emergency contraception. JAMA 2012; 307: 365-366

16 Wood AJ, Drazen JM, Greene MF. The politics of emergency contraception. NEJM 2012; 366: 101-102

17 Foth D, Göretzlehner G. Kontrazeption in der Perimenopause. Geburtsh Frauenheilk 2010; 70: 104-111

18 Wallwiener M, Wallwiener L-M, Seeger $H$ et al. Die Häufigkeit sexueller Funktionsstörungen unter deutschen Medizinstudentinnen und der Einfluss der Kontrazeption auf die Libido. Geburtsh Frauenheilk 2011; 71: 76-78

19 Reuther T, Bayrhammer J, Kerscher M. Verbesserung der Hautphysiologie bei Frauen durch ein Ethinylestradiol- und Chlormadinonacetathaltiges Kontrazeptivum. Geburtsh Frauenheilk 2010; 70: 1006-1010

Deutschsprachige Zusatzinformationen online abrufbar unter: www.thieme-connect.de/ejournals/toc/gebfra. 